\title{
CONTRIBUTIONS OF SEED PHYSICAL AND CHEMICAL CHARACTERS OF VARIOUS SORGHUM GENOTYPES (Sorghum bicolor [L.] Moench.) TO DAMAGED SEED INDUCED BY WEEVIL (Sitophilus sp.) DURING STORAGE
}

\author{
Eko Pramono ${ }^{1}$, Muhammad Kamal ${ }^{1}$, Franciscus Xaverius Susilo ${ }^{2}$, \& Paul Benyamin Timotiwu ${ }^{1}$ \\ ${ }^{1}$ Department of Agronomy, Faculty of Agriculture, University of Lampung, Indonesia \\ ${ }^{2}$ Department of Plant Protection, Faculty of Agriculture, University of Lampung, Indonesia \\ Jl. Prof. Dr. Sumantri Brodjonegoro No. 1 Bandar Lampung 35145 \\ E-mail: pramono.e61@gmail.com
}

\begin{abstract}
Contributions of seed physical and chemical characters of various sorghum genotypes (Sorghum bicolor [L.] Moench.) to damaged seed induced by weevil (Sitophilus sp.) during storage. The percentage of damaged seeds due to feeding by Sitophilus sp. during storage varied among sorghum genotypes (Sorghum bicolor [L.] Moench.). Some researchers reported that the difference was influenced by the physical and chemical characters of the seed grains. This study aimed to determine the contribution of seed physical and chemical characters and their effect model on the percentage of damaged seeds due to weevil attack during storage. Measurement of damaged seeds was carried out on 34 sorghum genotypes after they were stored for four months under storage temperatures of $26^{\circ} \mathrm{C}$ and $18^{\circ} \mathrm{C}$. Physical characters included seed hardness, weights of a thousand grains, pericarp thickness, and seed volume. Chemical characters of seeds included lipid, protein, carbohydrate, and tannin contents. Results of the study indicate that contribution of physical and chemical characters of sorghum seeds and their effect model on the percentage of damaged seeds due to weevil attack was different among storage under temperature of $26^{\circ} \mathrm{C}$ and under temperatures of $18^{\circ} \mathrm{C}$.
\end{abstract}

Key words: contribution, effect model, physical and chemical characters, seed, sorghum

\begin{abstract}
ABSTRAK
Kontribusi karakter fisik dan kimia benih berbagai genotip sorgum (Sorghum bicolor [L.] Moench.) pada benih rusak akibat kumbang bubuk (Sitophilus sp.) selama penyimpanan. Persentase benih rusak oleh serangan hama gudang kumbang bubuk Sitophilus sp. selama penyimpanan beragam antargenotipe sorgum (Sorghum bicolor [L.] Moench.). Beberapa peneliti melaporkan bahwa perbedaan itu dipengaruhi oleh sifat fisik dan kimia dari butiran benih. Penelitian ini bertujuan untuk mempelajari seberapa besar kontribusi dari sifat fisik dan kimia benih sorgum dan bagaimana model pengaruhnya pada persentase benih rusak akibat serangan Sitophilus sp. selama penyimpanan. Pengukuran persentase benih rusak itu dilakukan pada benih 34 genotipe sorgum setelah benih disimpan empat bulan pada ruang simpan dengan suhu $26^{\circ} \mathrm{C}$ dan $18{ }^{\circ} \mathrm{C}$. Karakter fisik mencakup kekerasan benih, bobot seribu butir, tebal perikarp, dan volume benih. Karakter kimia benih mencakup kadar lipid, protein, karbohidrat, dan tanin benih. Kontribusi karakter fisik dan kimia benih sorgum dan model pengaruhnya pada persentase kerusakan benih akibat kumbang bubuk selama penyimpanan dengan suhu $26{ }^{\circ} \mathrm{C}$ berbeda dibanding dengan selama penyimpanan dengan suhu $18^{\circ} \mathrm{C}$.
\end{abstract}

Kata kunci: benih, karakter fisik dan kimia, kontribusi, model pengaruh, sorgum

\section{INTRODUCTION}

Sorghum is a seed plant (spermatophyta) which belongs to the family of gramineae, the genus of sorghum and the species name of Sorghum bicolor [L.] Moench. Sorghum includes a superior food crop suitable to be developed in Indonesia to produce food, feed, bioethanol, and bioplastic. Per hectare of sorghum crop could produce 3-4 tons of seeds, 17-21 tons of fresh stover, and 3900-5700 L of ethanol (Pabendon et al., 2012) or even reach 6000-7000 L (Smith \& Buxton, 1993). As a food source, sorghum seeds contain $71 \%$ carbohydrates, $10.4 \%$ protein, and $3.1 \%$ fat, which is not inferior to nutrition in rice and wheat (RI Ministry of Health, 1992). 
Sustainable seeds provision through sorghum seed production and storage becomes one of the challenges for food crops dveleopment in Indonesia (Kamal, 2011). In storage, sorghum seeds may experience deterioration and physical damage by weevils (Sitophilus sp.) or by both corn weevils (Sitophilus zeamaiz Motsch.) (Keba \& Sori, 2013; Tefera et al., 2011) and rice weevils (Sitophilus oryzae L.) (Borikar \& Tayde, 1979; Adetunji, 1988). The weevil spreads all over the world and the population is increasingly high in the tropics (Koehler, 2012) such as in Indonesia. The weevil life cycle was accelerated at the environment with higher temperature and humidity (Yasin, 2009; Mansoor-ulHasan et al., 2017). In areas with high humidity and temperature, weevil attacks on sorghum seeds will increase and the seeds will deteriorate faster compared to those in the areas with low humidity and temperature. Therefore, weevils must be controlled, either by modifying the storage environment not suitable for pests or by storing seeds from genotypes relatively resistant to pest attacks (Susilo, 2011).

Weevil attacks made percentages of damage sorghum seeds and weight lose increased (Mekali et al., 2013; Borikar \& Tayde, 1979; Adetunji, 1988; Goftishu \& Belete, 2014). Percentage of damaged seeds is positively correlated to seed weight loss due to weevils and it varied among genotypes (Goftishu \& Belete, 2014). The percentage of seed weight loss was higher in the genotype with higher sensitivity index to weevils (Torres et al., 1996). The percentage of damage seed caused by the weevil attacks varied among sorghum genotypes (Goftishu \& Belete, 2014; Torres et al., 1996; Borikar \& Tayde, 1979; Adetunji, 1988), among rice genotypes (Hasheminia, 2011), and among corngenotypes (Santos et al., 2006).

The percentage of damage seeds caused by weevils attacks on sorghum seeds was also influenced by the protein content of the seeds, especially the lysine amino acid content (Goftishu \& Belete; 2014; Khani et $a l ., 2011)$. According to KEGG (Kyoto Encyclopedia of Genes and Genomes) (without years), lysine could become piperine by enzymatic reaction. Piperine is known as an organic pesticide that suppressed the weevil development in sorghum seeds (Khani et al., 2011). Sorghum seeds with high tannin and protein contents also experienced higher levels of weevil attacks than those with lower tannin and protein contents (Yasin, 2009).

In addition to the chemical content of the seed, the physical characters of seed grains such as seed surface shape and seed hardness also affected the weevil attacks level on sorghum seed (Yasin, 2009). The seed hardness also affected to the rate of weevil attacks on corn seed (Dimler, 1966). Seeds with furry and hard seed coat surfaces experienced lower weevil attacks rate than those with smooth and soft skin surfaces (Yasin, 2009). Larger seed grain size (> $20 \mathrm{mg}$ per grain) experienced higher weevil attacks compared to those smaller seeds (Campbell, 2002). The weevil prefered to feed on intact seeds of sorghum than sorghum flour (Wulandari et al., 2014).

Based on the above ideas, an empirical study was required to examine how much contribution of each seed physical and chemical characters on the percentage of damaged seeds of various sorghum genotypes due to weevil attacks during storage. This study aimed to examine the contribution of the seed physical and chemical characters of various sorghum genotypes and their effect model on the percentage of damaged seeds due to weevil attacks during storage, either in room temperature storage of $\pm 26^{\circ} \mathrm{C}$ or in air conditionedroom storage of $\pm 18{ }^{\circ} \mathrm{C}$. Here, the contribution meant the effect of one variable, either seed physical or chemical character, compared to the effect of whole variables on the percentage of damaged seed.

\section{MATERIALS AND METHODS}

Research site. The sorghum seeds of 34 genotypes were harvested from late July to early August of 2015 from farmland in Dusun Marhaen, Pekon Bumiaji, Anak Tuha Subdistrict, Central Lampung District, Indonesia. Measurement of the percentage of damaged seeds (PDS) due to weevil attacks during four months storage was conducted at the Seed and Plant Breeding Laboratory, Faculty of Agriculture, University of Lampung from November 2015 to February 2016. Physical and chemical characters of seed measurements were conducted at the Integrated Laboratory and Technology Innovation Center University of Lampung during January to June 2017.

Seed Preparation. Sorghum panicles were dried to $9.37 \pm 0.43 \%$ water content, then the seeds were separated from the panicles, and cleaned from all nonseed objects, so that good seeds were obtained and used as this experimental material. The thirty-four genotypes were Mandau, Kawali, P/W-WHP, Talaga Bodas, UPCA, Numbu, Super-1, and Super-2 (from Plant Breeding Research Institute of Maize and Cereals, Maros, Indonesia), Pahat, Samurai-1, Samurai-2, GHP1, GHP-3, GHP-5, GHP-11, GHP-29, GHP-33, GH-1, GH-2, GH-3, GH-4, GH-5, GH-6, GH-7, GH-8, GH-9, GH-10, GH-11, GH-12, GH-13, and GH-14 (generated 
from plant breeding program of the National Atomic Energy Agency (Batan), Serpong, Indonesia), and P/F5-193C, P/F-10-90A, and Cymmit (introduction lines from ICRISAT, India). The good seeds were then stored in the air-conditioned room with a temperature of \pm 18 ${ }^{\circ} \mathrm{C}$. The PDS measurement was conducted under storage temperature of $\pm 26^{\circ} \mathrm{C}$ and of $\pm 18{ }^{\circ} \mathrm{C}$.

Measurement of Damaged Seeds. The percentage of damaged seeds (PDS) caused by weevils after 4 months storage was measured using choice method, as opposed to the "no-choice method" as described by Torres et al. (1996); Adetunji (1988); Borikar \& Tayde (1979); Goftishu \& Belete (2014). Thirty-four plastic cups were arranged on the inside edge of a plastic tray. The diameter and the depth of the plastic tray were 50 $\mathrm{cm}$ and $3.5 \mathrm{~cm}$, respectively. The size of the plastic cup was the volume of $\pm 4 \mathrm{~mL}$, the cup mouth diameter of 3 $\mathrm{cm}$, the cup base diameter of $1.5 \mathrm{~cm}$, and the cup height of $2.5 \mathrm{~cm}$. The bottoms of plastic cups were attached to the plastic tray using glue. The arrangement of the 34 plastic cups formed a circle with radius of $\pm 25 \mathrm{~cm}$. The center of the circle was one cup as the cage for weevil invested into the system (Figure 1). Into each cup, 200 grains of seed from one sorghum genotype were included. In the cage, 100 weevils regardless of gender were included and then it was closed with plastic film layer. Shortly before the plastic tray sealed with plastic cover, the cage cover was opened by stabbing a pencil tip on the plastic cover, so the weevil could come out and spread to the seeds in the plastic cups. The plastic cover was then glued to the edge of the tray with plastic glue, so the weevil could not get out of the tray. Aeration system was created by making 10 small holes on plastic cover of the tray with needle tip. The measurement the damaged seed was conducted on two storages with different temperature, so one set kept in a room with a temperature of $\pm 26^{\circ} \mathrm{C}$ and another set kept in room with $\pm 18{ }^{\circ} \mathrm{C}$. In each storage room, the experiment was made for three replicates. Percentage of damaged seeds due to weevil attack was observed at the end of 4 months storage. After four months, the storage was terminated, and the damage seeds by weevil attack were calculated. The percentage of damage seeds was calculated as the percentage of damaged seeds of 200 whole seeds stored.

Measurement of Lipid, Carbohydrate, Protein, and Tannin Content. Lipid content (L) of sorghum seed was measured by Soxhlet Method using petroleum ether solvent according to AOAC method (AOAC, 2000a). Carbohydrate $(\mathrm{C})$ content of sorghum seed was

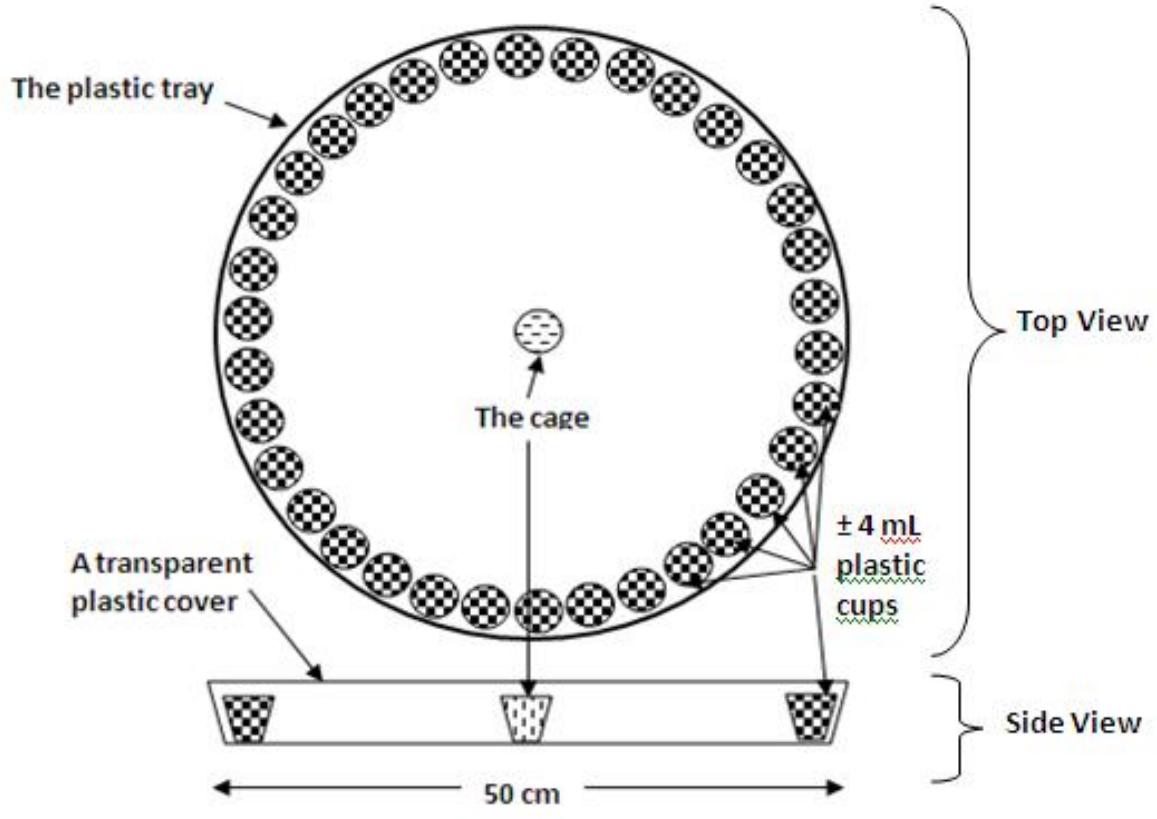

Figure 1. The choice method used for measuring the percentage of damaged seeds. Top view showed that the 34 plastic cups of $4 \mathrm{~mL}$ filled with 200 sorghum seeds were arranged circularly at the inside edge of the tray. At the centre of the circle was placed a cup as the cage where the weevil infested into the system. Side view showed that the system was covered with a transparent plastic. 
measured using Phenol Sulfuric Acid Method (DuBois et al., 1956) with a UV-Vis Carry 50 Spectrophotometer. Protein content $(\mathrm{P})$ of sorghum seed was measured by Kjeldal Method as described in AOAC procedure (AOAC, 2000b). Tannin (T) content of sorghum seed was measured by using the UV-Vis-Carry 100 Spectrophotometer according to Polshettiwar et al. (2007).

\section{Measurement of Physical Characters.}

The Seed Hardness ( $\mathrm{SH}$ ) of sorghum seed was measured by using FT 327 model of penetrometer. A sorghum seed with $8.5 \pm 0.4 \%$ moister content was placed directly on the penetrometer table and it was pressed with a pressure lever. The handle of the lever was withdrawn and the pressure lever pressed the seed, and when it was destroyed the value of seed hardness was read on the display screen in unit of $\mathrm{kg} / \mathrm{cm}^{2}$.

Pericarp Thickness (PT) of sorghum seed was measured by using Scanning Electron Microscope (SEM), Zeiss Evo MA-10. The dried sorghum seed was cut crosswise with a microtomal blade, and then the PT was displayed on screen. On the photograph of the SEM, the PT could be measured automatically on the display screen.

Seed volume (SV) was measured using the measuring glass method. The measuring glass used was one millilitre syringe tube. The syringe tube was filled with $0.5 \mathrm{ml}$ of water, and then 5 grains of sorghum seed were inserted into the syringe tube. The increase of water volume from $0.5 \mathrm{~mL}$ in the syringe tube was the volume of the 5 seeds. The volume of one grain of sorghum seed was the increase water volume in the syringe divided by five.

Weight of 1000 Grains (WTG) was measured on pure, clean, and dry seeds with $9.37 \pm 0.43 \%$ water content. Three times of 1000 grains seed were drawn randomly from a seeds lot of each sorghum genotype using Seed Buro 801 Count-A-Pak Model, then weighing them using the electric scales Ohaus Scout Pro Model to obtain the actual weight of 1000 grain (AWTG). Then, the WTG value at $10 \%$ water content was determined by counting it as $\mathrm{WTG}=[10 / 9.37] \times \mathrm{AWTG}$.

Experimental Design and Data Analysis. This experiment used a single factor of treatment, namely sorghum genotype consisting of 34 genotypes, which were applied in a randomized complete block design (RCBD) with three blocks as replicates. Blocking was done based on the observation time between blocks, with the time different of two days. Analysis of variance at 5\% level was used to see the effect of treatment simultaneously. The assumptions that must be met for the analysis of variance, namely the homogenity of variance among treatments and the aditivity of observed data had been done using Bartlett and Tukey Tests at $5 \%$ level of significance. The 5\% t-student test was used to compare the mean value of observations from the storage experiment at $26^{\circ} \mathrm{C}$ and at $18{ }^{\circ} \mathrm{C}$. Contribution and effect model of seeds physical and chemical characteristics on the percentage of damage seeds caused by weevil attacks was calculated from the results of path analysis. The variable effect coefficient (VEC) was the sum of coefficients of direct effect (CDE) and coefficients indirect effect (CIE) of each variable, so VEC $=$ CDE + CIE. The sum of variables effect coefficients (SVEC) was the sum of CVE. The contribution (CONT.) of each physical or chemical character was calculated as CONT $=(\mathrm{VEC} / \mathrm{SVEC}) \mathrm{x}$ $100 \%=(\mathrm{CDE}+\mathrm{CIE}) / \mathrm{SVEC} \times 100 \%$.

\section{RESULTS AND DISCUSSION}

Percentage of Damaged Seeds due to Weevil Attacks. The analysis of variance showed that the genotype effect on the percentage of damaged seed (PDS) was highly significance $(\mathrm{P}<0.01)$ either in seeds stored in room temperature $\left( \pm 26{ }^{\circ} \mathrm{C}\right)$ or in lower temperature storage $\left( \pm 18^{\circ} \mathrm{C}\right)$ (Table 1 and Figure 2). In the storage room with temperature $\pm 26^{\circ} \mathrm{C}$, the PDS due to weevil attack was much higher (9-fold) than those stored in the storage with temperature of $\pm 18^{\circ} \mathrm{C}$. This fact was consistent with Koehler's (2012) reports that the weevil rate regeneration was higher in areas with warmer temperatures. The percentages of damaged seeds among 34 sorghum genotypes were vary (Figure $2)$. Earlier researchers also reported there were differences in rates of weevil attacks among various genotypes (Goftishu \& Belete, 2014; Torres et al., 1996; Adetunji, 1988; Borikar \& Tayde, 1979). In this study, extreme percentage of damage seeds of Kawali was the least and GH-6 was the most (at storage temperatures $\pm 26^{\circ} \mathrm{C}$ ), or Samurai-1 and GHP-5 on storage with temperatures $\pm 18{ }^{\circ} \mathrm{C}$. There was a difference in genotype sequence for the percentage of damage seeds in the storage with the different temperature.

The Effect of Seed Physical and Chemical Characters on the Damaged Seeds. Data of this experiment indicate that there are five variables with 
Table 1. Percentage of damage seed by weevil attack (Sitophilus sp.) from 34 sorghum genotypes (Sorghum bicolor [L.] Moench.) after storage for 4 months

\begin{tabular}{lcccc}
\hline Parameter & At temperature $\pm 26^{\circ} \mathrm{C}$ & At temperature $\pm 18^{\circ} \mathrm{C}$ & t-value & P-Value \\
\hline Average (Damage Seed) & 53,2 & 5,9 & $49,23^{* *}$ & 0,000 \\
Standard deviation & 6,7 & 3,3 & & \\
Maximum & 70,1 & 18,3 & & \\
Minimum & 37,6 & 1,3 & & \\
\hline
\end{tabular}

$* *$ = highly significant $\mathrm{P}<0.01$.

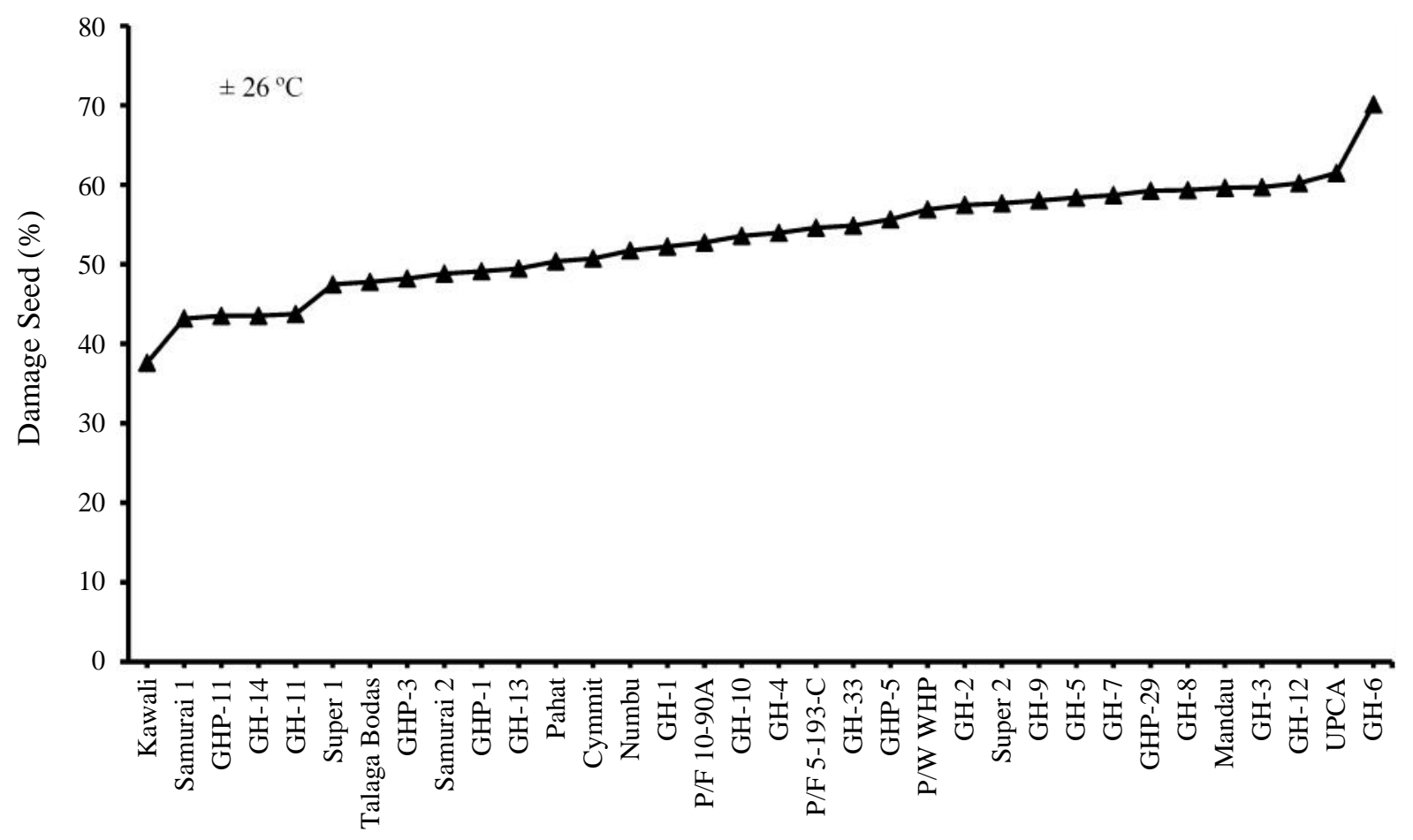

Genotypes

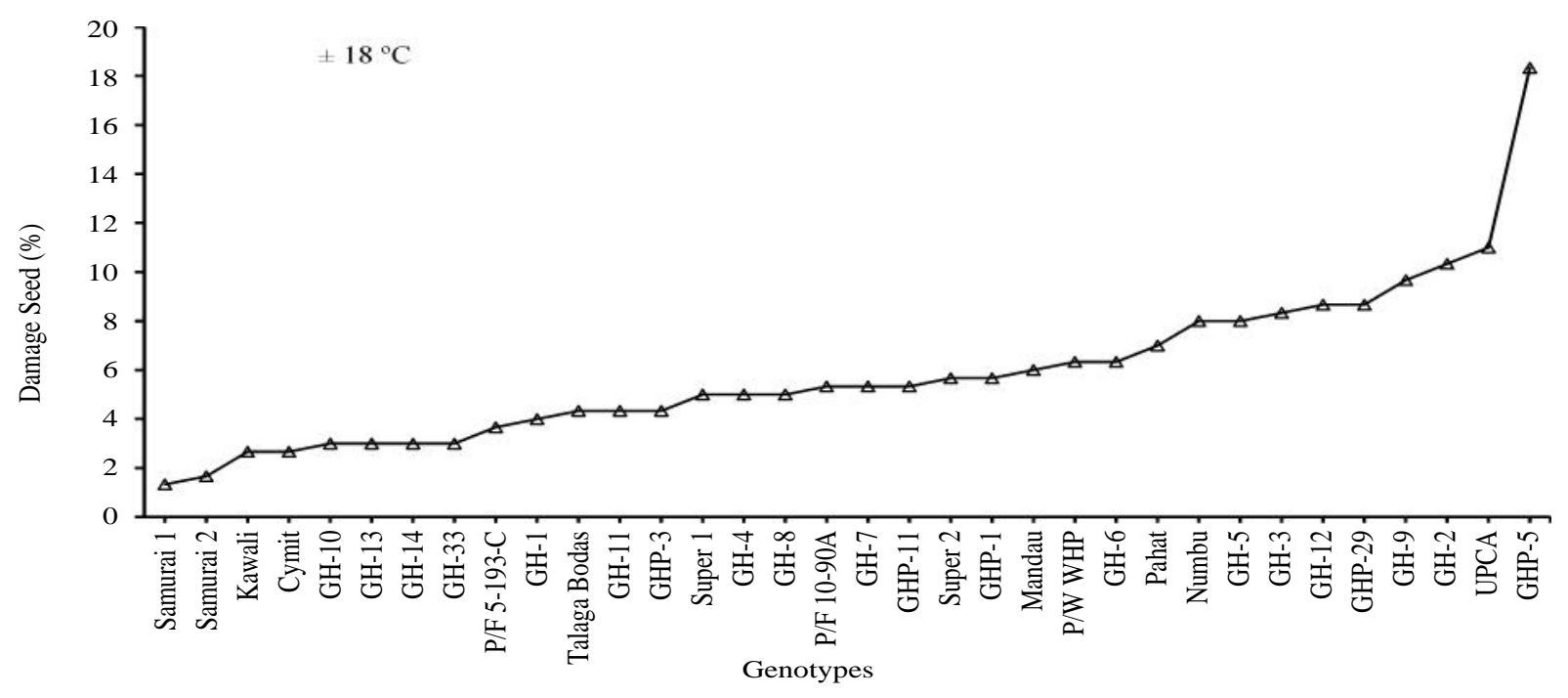

Figure 2. Percentage of damage seed by weevil (Sitophilus sp.) from 34 genotypes of sorghum seeds of after four months storage at $\pm 26^{\circ} \mathrm{C}\left(\right.$ ) and $\pm 18^{\circ} \mathrm{C}($ ) temperatures. 
large variance, i.e. carbohydrate (C), weight of 1000 grains (WTG), seed volume (SV), pericarp thickness (PT), and percentage of damage seeds after four months stored at $\pm 26^{\circ} \mathrm{C}$ (DSH) (Table 2). Correlation coefficients among variables showed that only ten out of 36 were significance, or only $28.8 \%$, either on the high temperature storage $\left( \pm 26^{\circ} \mathrm{C}\right)$ and on the low temperature storage $\left( \pm 18{ }^{\circ} \mathrm{C}\right.$ ) (Table 3$)$. The multivariate regressions (Table 4 and 5) showed only two variables, i.e tannine (T) and seed hardness $(\mathrm{SH})$ on high temperature storage $\left( \pm 26^{\circ} \mathrm{C}\right)$, and one variable pericarp thickness $(\mathrm{PT})$ on low temperature storage $( \pm$ $18^{\circ} \mathrm{C}$ ) that affected to the percentage of damaged seeds significantly. The low percentage of significance correlation coefficient $(28.8 \%)$ as well as low determination coefficient $\left(\mathrm{R}^{2}\right)(0.50$ and 0.44 , respectively) showed that there was a colinierity among exogenous variables (seed physical and chemical characters) (Asadi, 2012).

\section{Contribution of Seed Phsycal and Chemical Characters on the Percentage of Damaged Seeds.} This study showed that the contribution of each physical and chemical character of the various sorghum

Table 2. Variances of seed physical and chemical characters and percentage of damage seeds (PDS)_due to weevil attact (Sitophilus sp.) of 34 sorghum genotypes (Sorghum bicolor [L.] Moench.) during four months storage

\begin{tabular}{|c|c|c|c|c|c|c|c|c|c|c|}
\hline \multirow{2}{*}{ Parameters } & \multicolumn{4}{|c|}{ Chemical characters } & \multicolumn{4}{|c|}{ Physical characters } & \multicolumn{2}{|c|}{ PDS } \\
\hline & $\mathrm{L}$ & $\mathrm{P}$ & C & $\mathrm{T}$ & $\mathrm{SH}$ & WTG & SV & PT & DSL & DSH \\
\hline Average & 2.32 & 11.13 & 70.30 & 0.16 & 7.64 & 22.51 & 19.08 & 54.91 & 6.37 & 59.77 \\
\hline St.Dev & 0.37 & 1.17 & 4.65 & 0.16 & 1.16 & 4.19 & 4.43 & 16.33 & 3.01 & 12.83 \\
\hline Variance & 0.14 & 1.38 & 21.59 & 0.03 & 1.35 & 17.56 & 19.66 & 266.62 & 9.05 & 164.56 \\
\hline Maximum & 3.66 & 13.73 & 82.17 & 0.68 & 9.97 & 29.59 & 28.67 & 86.45 & 16.28 & 84.28 \\
\hline Minimum & 1.61 & 9.16 & 59.93 & 0.04 & 5.21 & 14.57 & 9.33 & 25.40 & 1.67 & 29.22 \\
\hline
\end{tabular}

$\mathrm{L}=$ lipid (\%); $\mathrm{P}=$ protein $(\%) ; \mathrm{C}=$ carbohydrat $(\%) ; \mathrm{T}=\operatorname{tannin}(\%) ; \mathrm{SH}=$ seed hardness $\left(\mathrm{kg} / \mathrm{cm}^{2}\right)$; WTG=weight of thousand grain $(\mathrm{g}) ; \mathrm{SV}=$ seed volume $(\mathrm{mL})$; and $\mathrm{PT}=$ pericarp thickness $(\mu \mathrm{m})$; DSL=percentage of damage seed after four months stored at temperature $\pm 18{ }^{\circ} \mathrm{C}(\%)$; dan $\mathrm{DSH}=$ percentage of damage seed after four months stored at temperature $\pm 26^{\circ} \mathrm{C}(\%)$.

Table 3. Correlation coefficient among exogenous (Xi) and endogenous variables (Y) Koefisien korelasi antarvariabel dari benih sorgum yang disimpan pada suhu $\pm 26^{\circ} \mathrm{C}$ dan $\pm 18^{\circ} \mathrm{C}$

\begin{tabular}{|c|c|c|c|c|c|c|c|c|c|c|}
\hline & \multicolumn{8}{|c|}{$\mathrm{X} i$} & \multicolumn{2}{|c|}{$\mathrm{Y}$} \\
\hline & $\mathrm{L}$ & $\mathrm{P}$ & C & $\mathrm{T}$ & $\mathrm{SH}$ & WTG & SV & PT & DSH & DSL \\
\hline $\mathrm{L}$ & 1.00 & -0.05 & -0.20 & $0.55^{* *}$ & 0.01 & 0.00 & 0.06 & -0.02 & -0.01 & 0.05 \\
\hline $\mathrm{P}$ & & 1.00 & -0.24 & $-0.35^{*}$ & $-0.42 *$ & $-0.49^{* *}$ & $-0.43^{*}$ & -0.09 & -0.06 & 0.16 \\
\hline $\mathrm{C}$ & & & 1.00 & -0.09 & 0.07 & -0.21 & -0.11 & -0.13 & $-0.34 *$ & $-0.40^{*}$ \\
\hline $\mathrm{T}$ & & & & 1.00 & 0.18 & 0.09 & 0.15 & 0.08 & 0.27 & 0.08 \\
\hline $\mathrm{SH}$ & & & & & 1.00 & $0.67 * *$ & $0.57 * *$ & 0.16 & -0.06 & -0.11 \\
\hline WTG & & & & & & 1.00 & $0.80 * *$ & 0.22 & 0.31 & 0.14 \\
\hline SV & & & & & & & 1.00 & 0.15 & $0.40 *$ & 0.00 \\
\hline PT & & & & & & & & 1.00 & 0.12 & $0.48 * *$ \\
\hline
\end{tabular}

$\mathrm{L}=$ lipid $(\%) ; \mathrm{P}=$ protein $(\%) ; \mathrm{C}=$ carbohydrat $(\%) ; \mathrm{T}=\operatorname{tannin}(\%) ; \mathrm{SH}=\mathrm{Seed}$ hardness $\left(\mathrm{kg} / \mathrm{cm}^{2}\right)$; WTG=weight of thousand grain $(\mathrm{g}) ; \mathrm{SV}=$ seed volume $(\mathrm{mL})$; and PT=pericarp thickness $(\mu \mathrm{m}) ; \mathrm{DSL}=$ percentage of damage seed after four months stored at temperature $\pm 18{ }^{\circ} \mathrm{C}(\%)$; dan DSH =percentage of damage seed after four months stored at temperature $\pm 26^{\circ} \mathrm{C}$; r-table $(\mathrm{n}=32 ; 5 \%)=0,34 ; \mathrm{r}$-table $(\mathrm{n}=32 ; 1 \%)=0,44 ; *$ and $* *$ significant at level $5 \%$ and $1 \%$, respectively. 
Table 4. Results of regression analysis and path analysis for the effect of exogenous variables (Xi) on percentage of damaged seeds of sorghum due to weevil attact after four months stored at $\pm 26^{\circ} \mathrm{C}$ (DSH) as the endogenous variables $(\mathrm{Y})$

\begin{tabular}{|c|c|c|c|c|c|c|c|}
\hline \multirow{2}{*}{$\begin{array}{l}\text { Exogenous } \\
\text { variables }\end{array}$} & \multicolumn{3}{|c|}{ Regression analysis } & \multicolumn{4}{|c|}{ Path analysis } \\
\hline & Reg.- Coef. & P-value & $\mathrm{r}-\mathrm{XY}$ & $\mathrm{CDE}$ & $\mathrm{CIE}$ & $\mathrm{CDE}+\mathrm{CIE}$ & CONT.(\%) \\
\hline $\mathrm{L}$ & -11.69 & 0.06 & -0.01 & -0.34 & 0.33 & -0.01 & -1.84 \\
\hline $\mathrm{P}$ & 2.07 & 0.34 & -0.06 & 0.19 & -0.25 & -0.06 & -9.81 \\
\hline $\mathrm{C}$ & -0.46 & 0.35 & $-0.34 *$ & -0.16 & -0.18 & -0.34 & -54.26 \\
\hline $\mathrm{T}$ & $39.93 *$ & 0.01 & 0.27 & 0.51 & -0.24 & 0.27 & 43.15 \\
\hline $\mathrm{SH}$ & $-5.94 *$ & 0.01 & -0.06 & -0.54 & 0.48 & -0.06 & -10.08 \\
\hline WTG & 1.01 & 0.30 & 0.31 & 0.33 & -0.02 & 0.31 & 49.88 \\
\hline SV & 1.27 & 0.08 & $0.40^{*}$ & 0.44 & -0.04 & 0.40 & 63.19 \\
\hline PT & 0.02 & 0.88 & 0.12 & 0.02 & 0.10 & 0.12 & 19.77 \\
\hline Total & & & & 0.45 & 0.18 & SVEC $=0.63$ & 100.00 \\
\hline
\end{tabular}

L=lipid (\%); $\mathrm{P}=$ protein (\%); $\mathrm{C}=$ carbohydrat (\%); T=tannin (\%); $\mathrm{SH}=$ Seed hardness $\left(\mathrm{kg} / \mathrm{cm}^{2}\right) ; \mathrm{WTG}=$ weight of $\mu \mathrm{m})$; Reg.-Coef. $=$ regression_coefficient,

$\mathrm{P}$-value=nilai peluang, $\mathrm{r}-\mathrm{XY}=$ correlation coefficient variable $\mathrm{X}$ and $\mathrm{Y} ; \mathrm{CDE}=$ coefficient of direct effect, $\mathrm{CIE}=$ coefficient of indirect effect; $\mathrm{SVEC}=$ sum of variable effect coefficient; $\mathrm{CONT}$.=contribution; $\mathrm{DSH}=86.89$ 11.69L+2.07P-0.46C+39.93*T-5.94*SH+1.01WTG+1.27SV+0.02PT; $\mathrm{R}^{2}=0.50 * ; *$ and $* *=$ significant at level $5 \%$ and $1 \%$, repectively.

Table 5. Results of regression analysis and path analysis for the effect of exogenous variables (Xi) on percentage of damaged seeds of sorghum due to weevil attact after four months stored at $\pm 18^{\circ} \mathrm{C}$ (DSL) as the endogenous variables (Y)

\begin{tabular}{|c|c|c|c|c|c|c|c|}
\hline \multirow{2}{*}{$\begin{array}{l}\text { Exogenous } \\
\text { variables }\end{array}$} & \multicolumn{3}{|c|}{ Regression analysis } & \multicolumn{4}{|c|}{ Path analysis } \\
\hline & Reg.- Coef. & P-value & $\mathrm{r}-\mathrm{XY}$ & $\mathrm{CDE}$ & $\mathrm{CIE}$ & $\mathrm{CDE}+\mathrm{CIE}$ & CONT.(\%) \\
\hline $\mathrm{L}$ & -0.45 & 0.76 & 0.05 & -0.06 & 0.11 & 0.05 & 12.47 \\
\hline$P$ & 0.62 & 0.25 & 0.16 & 0.24 & -0.09 & 0.16 & 38.73 \\
\hline $\mathrm{C}$ & -0.12 & 0.32 & $-0.40^{*}$ & -0.19 & -0.22 & -0.40 & -99.12 \\
\hline $\mathrm{T}$ & 3.63 & 0.34 & 0.08 & 0.20 & -0.11 & 0.08 & 20.83 \\
\hline $\mathrm{SH}$ & -0.78 & 0.18 & -0.11 & -0.30 & 0.19 & -0.11 & -25.89 \\
\hline WTG & 0.37 & 0.13 & 0.14 & 0.52 & -0.37 & 0.14 & 35.19 \\
\hline SV & -0.17 & 0.34 & 0.00 & -0.25 & 0.25 & 0.00 & 0.33 \\
\hline PT & $0.08 * *$ & 0.01 & $0.48 * *$ & 0.43 & 0.05 & 0.48 & 117.47 \\
\hline Total & & & & 0.60 & -0.19 & SVEC $=0.41$ & 100.00 \\
\hline
\end{tabular}

$\mathrm{L}=$ lipid (\%); $\mathrm{P}=$ protein (\%); $\mathrm{C}=$ carbohydrat (\%); T=tannin (\%); $\mathrm{SH}=$ Seed hardness $\left(\mathrm{kg} / \mathrm{cm}^{2}\right)$; WTG=weight of thousand grain $(\mathrm{g}) ; \mathrm{SV}=$ seed volume $(\mathrm{mL})$; and $\mathrm{PT}=$ pericarp thickness $(\mu \mathrm{m})$; Reg.-Coef. $=$ regression coefficient, $\mathrm{P}$-value=nilai peluang, $\mathrm{r}-\mathrm{XY}=$ correlation coefficient variable $\mathrm{X}$ and $\mathrm{Y} ; \mathrm{CDE}=$ coefficient of direct effect, $\mathrm{CIE}=$ coefficient of indirect effect; $\mathrm{SVEC}=$ sum of variable effect coefficient; $\mathrm{CONT} .=$ contribution; $\mathrm{DSL}==4.82$ $0.45 \mathrm{~L}+0.62 \mathrm{P}-0.12 \mathrm{C}+3.63 \mathrm{~T}-0.78 \mathrm{SH}+0.37 \mathrm{WTG}-0.17 \mathrm{SV}+0.08 * \mathrm{PT} ; \mathrm{R}^{2}=0.44 * ; *$ and $* *=$ significant at level $5 \%$ and $1 \%$, respectively. 
genotypes on the percentage of damaged seeds due to weevil during storage at high temperatures $\left(26^{\circ} \mathrm{C}\right)$ was different from those at low temperatures $\left(18^{\circ} \mathrm{C}\right)$. The difference took place either in the contribution direction and/or in the contribution magnitude. In addition to the magnitude and direction of the contribution, differences due to storage temperature also occur in the order of variables. At the storage temperature of $\pm 26^{\circ} \mathrm{C}$, the order of variables based on the magnitude of the contribution was as follows; seed volume (SV) 63.19\%, weight of thousand grain (WTG) 49,88\%, tannin 43.15\%, pericarp thickness (PT) $19.77 \%$, lipid (L) $-1.84 \%$, protein (P) $-9.81 \%$, seed hardness $(\mathrm{SH})-10,08 \%$, and seed carbohydrate (C) $-54,26 \%$ (Table 4). While at the storage temperature $\pm 18{ }^{\circ} \mathrm{C}$, the order of variables based on the magnitude of the contribution was as follows; pericarp thickness (PT) $117.47 \%$, protein (P) 38.73\%, weight of thousand grain (WTG) $35.19 \%$, tannin (T) 20.83\%, lipid (L) $12.47 \%$, seed volume (SV) $0.33 \%$, seed hardness $(\mathrm{SH})-25.89 \%$, and carbohydrat (C) $-99.12 \%$ (Table 5).

The effect direction was shown by negative or positive sign before the number of contribution (Tabel 4 and 5). The seed characters of tannin (T), weight of thousand grains (WTG), seed volume (SV), and pericap thickness (PT) gave positive contribution which meant

(A)

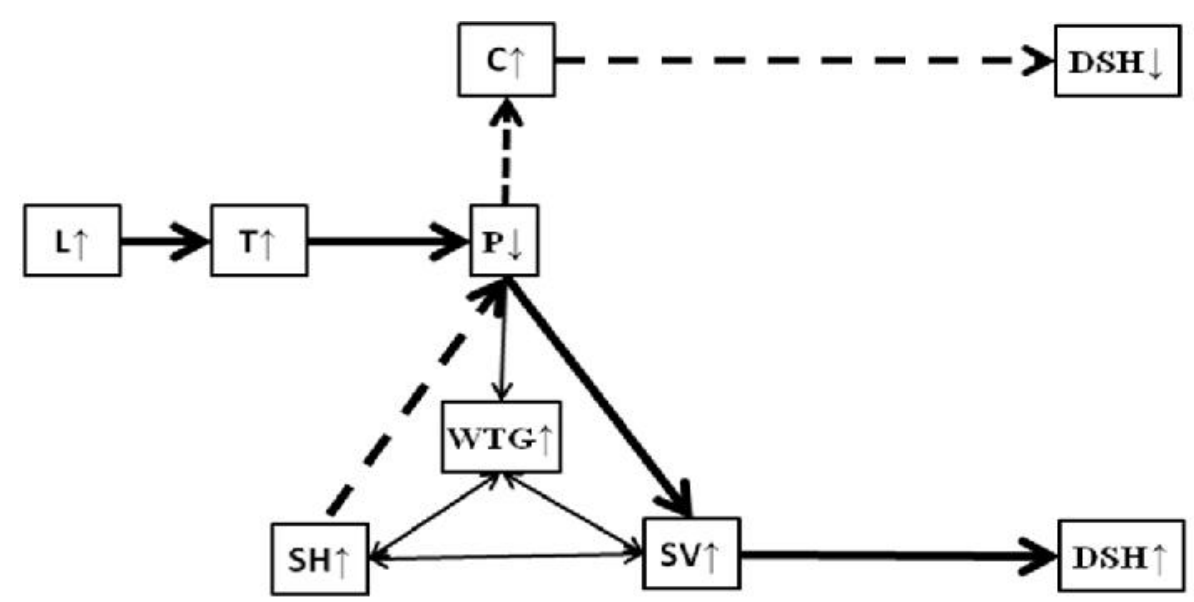

(B)

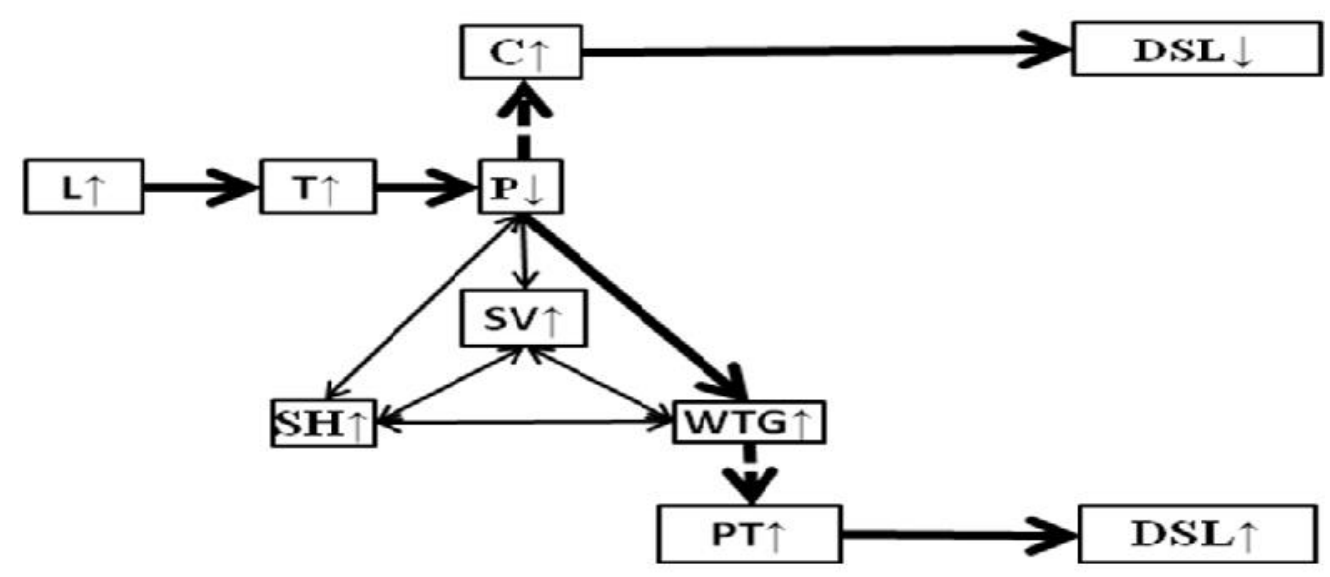

Figure 3.The model direct effect (DE) and indirect effect (IE) of physical and chemical characters of various of sorghum genotypes seeds on the percentage of damage seeds due to weevil attack (Sitophilus sp.) after four months storage at temperature of $\pm 26^{\circ} \mathrm{C}$; (A). (DSH) and at temperature of $\pm 18{ }^{\circ} \mathrm{C}$, (B). (DSL); $\mathrm{L}=$ lipid $(\%) ; \mathrm{P}=$ protein $(\%) ; \mathrm{C}=$ carbohydrat $(\%) ; \mathrm{T}=\operatorname{tannin}(\%) ; \mathrm{SH}=$ Seed hardness $\left(\mathrm{kg} / \mathrm{cm}^{2}\right)$; WTG=weight of thousand grain $(\mathrm{g})$; $\mathrm{SV}=$ seed volume $(\mathrm{mL})$; and $\mathrm{PT}=$ pericarp thickness $(\mu \mathrm{m})$; $\longleftrightarrow$ : significant correlation $(\mathrm{P}<0,05),\langle-\rangle=$ non-significant correlation, and $\rightarrow=$ pathway model of tannin effect to DSH or DSL, and $\mathbf{- \boldsymbol { - }}$ = pathway model of seed hardness effect (SH) to DSH. 
that the variables increased the percentage of seeds damaged by weevil attacks during storage, both in the high temperature storage of $\pm 26^{\circ} \mathrm{C}$ (DSH) and in the low temperature storage of $\pm 18{ }^{\circ} \mathrm{C}$ (DSL). The characters of seed hardness $(\mathrm{SH})$ and seed carbohydrate content (C) gave negative contribution or decrease DSH and DSL. The characters of seed lipid content (L) and seed protein content $(\mathrm{P})$ gave negative contribution or reduce DSH but it gave positive contribution or increase DSL. In general, The seed physical characters gave positive contribution to the percentage of damaged seeds by weevil, which an average of $30.69 \%$ to DSH and $31.78 \%$ to DSL, more than the seed chemical characters contribution, that were $-5.69 \%$ to DSH and $-6.77 \%$ to DSL. Three seed physical characters gave positive contribution to DSH and DSL, that were weight of thousand grains (WTG), seed volume (SV), and pericap thickness (PT), and one physical character that gave negative contribution was seed hardness $(\mathrm{SH})$. The seed chemical characters that gave positive contribution to DSH and DSL was tannin (T), that gave negative contribution to DSH and DSL was seed carbohydrate content $(\mathrm{C})$, while that gave negative contribution to DSH but gave positive contribution to DSL were seed lipid content $(\mathrm{L})$ and seed protein content $(\mathrm{P}$ The probable scientific argumentation explaining that occurence like that was presented in next paragraph.

\section{The Effect Model of Seed Physical and Chemical Characters on the Percentage of Damaged Seeds.}

Based on the values of correlation coefficients $\mathrm{r}$-XiY (Table 3), regression coefficients, coefficients of direct effect (CDE) and coefficients of indirect effect (CIE) (Table 4 and 5), the effect model of seed physical and chemical characters of various sorghum genotypes on percentage of damaged seeds was interprated as shown in Figure 3. In the high temperature storage room $( \pm 26$ ${ }^{\circ} \mathrm{C}$ ), the positive correlation of seed volume (SV) and percentage of damage seed (DSH) was significant ( $r=$ $0.40 ; \mathrm{P}<0.05$ ) (Table 3 ). It indicated that when the value of SV increased then DSH also increased (or the increase of SV value was followed by the increase of DSH). This result was consistent with Yasin (2009) and Campbell (2002) reports that weevil prefered to largesized of sorghum seeds. However, SV was negatively correlated with seed protein $(\mathrm{P})$ content $(\mathrm{P}<0.05)$. It indicated that if the value of SV increased then the seed protein content $(\mathrm{P})$ decreased. When the seed $\mathrm{P}$ content was low then the seed carbohydrate (C) content was high. The seed carbohydrate (C) was also affected by seed hardness ( $\mathrm{SH})$. If $\mathrm{SH}$ was high then the seed protein
(P) was low and seed carbohydrate (C) was high. The results of this study supported the Dimler's study (1966) that sorghum seed with high carbohydrate $(\mathrm{C})$ content would be less favored by the weevil. The positive correlation of seed tannin content (T) and seed lipid (L) was significant, whereas the correlation of $\mathrm{L}$ and $\mathrm{P}$ was not significant (Table 3). If $\mathrm{T}$ was high then $\mathrm{P}$ was low. If $\mathrm{P}$ was low then $\mathrm{SV}$ was high, and seeds with high SV were favored by weevils. Thus, the higher seed tannin content would increase the weevil attack on sorghum seeds. This was also reported by Yasin (2009). Low content of seed protein was also caused by the high seed hardness $(\mathrm{SH})$, and $\mathrm{SH}$ would also be increased by seed volume (SV). Thus, in addition to increase the rate of weevil attact, the seed volume would decrease rate of weevil attack. Low seed protein $(\mathrm{P})$ content would increased seed carbohydrate $(\mathrm{C})$, and seed with high in $\mathrm{C}$ would decrease the DSH. Thus, during storage under temperatures of $\pm 26^{\circ} \mathrm{C}$, the influence of physical and chemical characters of seeds on percentage of damage seeds (DSH) was observed that seed lipid content $(\mathrm{L})$ in line with high levels of tannin $(\mathrm{T})$, tannin correlated negatively to seed protein $(\mathrm{P})$, seed protein correlated negatively to seed volume (SV), and SV correlated positively to damaged seeds. Seed volume (SV) correlated directly to damaged seeds (DSH). In contrast, the high seed hardness (SH) lowered seed protein $(\mathrm{P})$ and increased seed carbohydrate $(\mathrm{C})$. The seed containing high carbohydrate $(\mathrm{C})$ would reduce DSH. The effect model of tannin (T) to DSH was indirect effect that was through the seed protein $(\mathrm{P})$ content, then to seed volume (SV), and ended in DSH. The sorghum seed with high tannin content $(\mathrm{T})$ would have low protein $(\mathrm{P})$ content and high seed volume (SV). The sorghum seeds with high seed volume (SV) would be more preferred by weevil than those the low one. This was consistent with Campbell's (2002) report, that weevil prefered to large sorgum seeds ( $>20 \mathrm{mg} /$ grains). The effect model of seed hardness ( $\mathrm{SH}$ ) on DSH was also indirect effect, that was through seed protein (P), then to seed carbohydrate (C), and ended in DSH. The sorghum seeds with high seed hardness $(\mathrm{SH})$ would have low protein $(\mathrm{P})$ content, high carbohydrate $(\mathrm{C})$ content, and they would not be preferred by weevil.

At $\pm 18{ }^{\circ} \mathrm{C}$ storage room, multiple regression analysis showed that only coefficient of pericarp thickness $(\mathrm{PT})$ variable was highly significant $(\mathrm{P}<0.01)$, while other coefficients of seed physical and chemical character variables were not significant (Table 5). The PT variable significantly correlated to percentage of damaged seed at low temperature storage of $\pm 18{ }^{\circ} \mathrm{C}$ 
(DSL) ( $\mathrm{r}=0.48 ; \mathrm{P}<0.01)$. The PT variable also had a regression coefficient of $0.08(\mathrm{P}<0.01)$ that was high significance, had a high coefficient of direct effect (CDE) of 0.43, had a coefficient of indirect effect (CIE) of 0.05 , and the coefficient of variable effect (CVE) of 0.48 . It meant that PT with 0.08 regression coefficient had a 0.48 direct effect on DSL. Carbohydrates (C) had small CDE and CIE, i.e. -0.19 and -0.22 respectively, and its regression coefficient was not significant -0.12 , but it had a significant correlation coefficient $(\mathrm{P}<0.05)$ as large as -0.40 . Although the regression coefficient was relatively small $(0.08)$, it was highly significant $(\mathrm{P}$ $<0.01$ ), so its contribution to DSL was the highest, i.e. $117.47 \%$. The PT's contribution was DSL adding. In contrast, seed carbohydrate (C) contributed the smallest coefficient of variable effect (CVE), i.e. $-99.12 \%$. It was DSL reducing (Table 5).

The other variables such as lipid (L), protein $(\mathrm{P})$, tannin (T), seed hardness ( $\mathrm{SH})$, weight of thousand grains (WTG), and seed volume (SV) had small total influences with small contribution percentages, and with non-significant regression coefficient $(\mathrm{P}>0.05)$. The weight of thousand grains (WTG) had a large direct effect coefficient of 0.52 , and the indirect effect coefficient was small enough, i.e. -0.37 , so the sum of effect coefficient was small 0.14 . The indirect effect of WTG was estimated through the pericarp thickness (PT). Thus, at the $\pm 18{ }^{\circ} \mathrm{C}$ storage room, the sorghum seed physical character variables that greatly contributed to DSL was the pericarp thickness (PT), that was $117.74 \%$. This contribution was showed in a highly significant regression coefficient $(\mathrm{P}<0.01)$ as an increasing DSL variable. The correlation of seed carbohydrate content $(\mathrm{C})$ and percentage of damaged seed (DSL) was -0.40 and it was significant $(\mathrm{P}<0.05)$, and it contributed the largest ammount in reducing of DSL by $-99.12 \%$, although by the non-significant regression coefficient of -0.12 .

The effect of seed carbohydrat (C) was directly to DSL with a significant correlation coefficient of $-0.40(\mathrm{P}<0.05)$ and with a coefficient of total effect of -0.40 . The effect of $\mathrm{C}$ variables was DSL reducer. In addition to $\mathrm{C}$ variable, there were other variables affecting DSL indirectly through the $\mathrm{C}$ variable, that were the seed hardness $(\mathrm{SH})$ and seed protein $(\mathrm{P})$. The effect of tannin (T) on DSL was indirect effect that was through protein $(\mathrm{P})$, then onto the weight of a thousand grains (WTG), then onto the pericarp thickness (PT), and ended to DSL. The effect of PT was a DSL increasing with a significant regression coefficient of $+0.08(\mathrm{P}<0.01)$ (Table 5 and Figure 3). This DSL increasing effect of PT could be from the indirect effects of WTG that was positively correlated to PT (Table 3). Seeds with high WTG would also be high in SV and PT. Thus, the direction effect of PT was a DSL increasing by the largest contribution of $117.47 \%$, though with a small highly significant $(\mathrm{P}<0.01)$ regression coefficient of 0.08 .

Seed protein $(\mathrm{P})$ became a chemical character that can indirectly affect the percentage of damage seeds through other physical and chemical characters. Seed protein $(\mathrm{P})$ could also be an intermediate variable for seed physical character, such as seed hardness ( $\mathrm{SH}$ ) (Figure 3A) or other chemical character, such as tannin (T) (Figure 3A and $\mathrm{B}$ ) in affecting the percentage of damaged seeds, which was either stored in a room with temperature of $\pm 26^{\circ} \mathrm{C}$ or $\pm 18{ }^{\circ} \mathrm{C}$.

\section{CONCLUSION}

The contribution of seed physical and chemical characters on damaged seed due to weevils during four months storage at $\pm 26{ }^{\circ} \mathrm{C}$ temperature (DSH) was different from those at $\pm 18^{\circ} \mathrm{C}$ (DSL). The seed physical characters that gave positive contribution to DSH and DSL were seed tannin (T), weight of thousand grains (WTG), and pericarp thickness, while one that gave negative contribution was seed hardness $(\mathrm{SH})$. The chemical character that gave positive contribution to DSH and DSL was seed tannin (T), that gave negative contribution to DSH and DSL was seed carbohydrate (C), and that gave negative contribution to DSH and positive contribution to DSL were seed lipid (L) and seed protein $(\mathrm{P})$. The probable effect model of them on DSH was lipid (L) onto tannin (T) onto protein $(\mathrm{P})$, then deviding onto seed carbohydrate (C) and seed volume (SV), and that respectively ended in damaged seed (DSH). The probable effect model of them on DSL was lipid (L) onto tannin (T) onto protein (P); then deviding onto seed carbohydrate (C) and ended in damaged seed (DSL), and onto the weight of a thousand grains (WTG), onto pericarp thickness (PT), and ended in damaged seeds (DSL).

\section{ACKNOWLEDGMENTS}

The funding of this research came partly from the University of Lampung through the grant No. 549/ UN26/8/LPPM/2015. We would like to thank the University of Lampung. We also thank Dr. Trikosumaningtyas (Professor at IPB Bogor), Dr. Soeranto Human and Dr. Sihono (Professor of research 
at The National Atomic Energy Agency, BATAN); and Dr. Amin Nur (Professor of research at The Corn and Cereal Crops Research Institute) for supporting us with the sorghum seeds used in this research.

\section{REFERENCES}

Adetunji JF. 1988. A study of the resistance of some sorghum seed cultivars to Sitophilus oryzae (L.) (Coleoptera: Curculionidae). J. Stored Prod. Res. 24(2): 67-71.

AOAC. 2000a. AOAC Official Methods of Analysis: Animal Feed. Chapter 4, page 5.

AOAC. 2000b. Analytical Methods: Determination of protein content. Pp. 141-142.

Asadi. 2012. Sidik lintas karakter agronomi dan ketahanan hama pengisap polong terhadap hasil plasma nutfah kedelai. Bull. Plasma Nutfah 18 (1): $1-8$.

Borikar PS \& Tayde DS. 1979. Resistance in sorghum to Sitophilus oryzae Linn. Proc. Indian Acad. Sci. 88B(4): 273-276.

Campbell JF. 2002. Influence of seed size on exploitation by the rice weevil, Sitophilus oryzae. J. Insect Behav. 15(3): 429-445.

Dimler RJ. 1966. Report on kernel structure and wet milling of high lysine corn. In: Mertz ET \& OE Nelson (Eds.) Proceeding of High Lysine Corn Conference. Pp. 121-127. Purdue University. Washington, D.C. 1966. Industries Research Fondation.

DuBois M, Gilles KA, Hamilton JK, Rebers PA, \& Smith F. 1956. Colorimetric method for determination of sugars and related substances. Anal. Chem. 28(3): 350-356.

Goftishu M \& Belete K. 2014. Susceptibility of sorghum varieties to maize weevil (Sitophilus zeamais Motschulsky) (Coleoptera: Curculionidae). Afr. J. Agric. Res. 9(31): 2419-2426.

Hasheminia SM. 2011. The study of food preference of Sitophilus oryzae $\mathrm{L}$. on common cultivars of rice in Guilan province. J. Am. Sci. 7(6): 430-434.

Kamal M. 2011. Study of Synergy for the Utilization of Light and Nitrogen in the Production of Food Crops. Scientific Oration for the Inauguration of Professor of Lampung University. Bandar Lampung 23 February 2011 (in Bahasa Indonesia)
Keba T \& Sori W. 2013. Differential resistance of maize varieties to maize weevil (Sitophilus zeamais Motschulsky) (Coleoptera: Curculionidae) under laboratory condition. J. Entomol. 10(1): 1-12.

KEGG (Kyoto Encyclopedia of Genes and Genomes). Without Year. Tropane, piperidine and pyridine alkaloid biosynthesis - Reference pathway. http:/ / w w w . k e g g . j p / k e g g - b i n / show_pathway?map00960. Accessed on December, 31 2017, at 12:26 PM.

Khani M, Awang RM, Omar D, Rahmani M, \& Rezazadeh S. 2011. Tropical medicinal plant extracts against rice weevil, Sitophilus oryzae L. J. Med. Plant Res. 5(2): 259-265.

Koehler PG. 2012. Rice Weevil, Sitophilus oryzae (Coleoptera: Curculionidae). Entomology and Nematology Department, UF/IFAS Extension, Gainesville.

Mansoor-ul-Hasan, Aslam A, Jafir M, Javed MW, Shehzad M, Chaudhary MZ, \& Aftab M. 2017. Effect of temperature and relative humidity on development of Sitophilus oryzae L. (Coleoptera: Curculionidae). J. Entomol. Zool. Stud. 5(6): 85-90.

Mekali J, Naganagoud A, Sreenivas AG, Somasekhar \& Nidoni U. 2013. Management of Sitophilus oryzae (L.) (Coleoptera: Curculionidae) under modified atmospheric condition on stored sorghum. Ann. Biol. Res. 4(7): 185-192.

Pabendon MB, Mas'ud S, Sarungallo RS, \& Nur A. 2012. Penampilan fenotipik dan stabilitas sorgum manis untuk bahan baku bioetanol. J. Penel. Pertanian Tanaman Pangan 31(1): 60-69.

Polshettiwar SA, Ganjiwale RO, Wadher SJ, \& Yeole PG. 2007. Spectrophotometric estimation of total tannins in some ayurvedic eye drops. Indian J. Pharm. Sci. 69(4): 574-576.

RI Ministry of Health. 1992. List of food ingredients. Jakarta: Bhratara (in Bahasa Indonesia).

Santos JP, Guimaraes PEO, Waquil JM, \& Foster JE. 2006. Relative index of susceptibility to the maize weevil, Sitophilus zeamais, among some QPM corn lines. Rev. Bras. Milho Sorgo 5(2): 159169. 
Smith GA \& Buxton DR. 1993. Temperate zone sweet sorghum ethanol production potential. Bioresour. Technol. 43(1): 71-75.

Susilo FX. 2011. The existence of Insects in the Agricultural Ecosystem: Diversity, Interrelation, and Prospects Management Biorasional. Scientific Oration for the Inauguration of Professor of Lampung University. Bandar Lampung 23 February 2011. (in Bahasa Indonesia).

Tefera T, Mugo S, \& Likhayo P. 2011. Effects of insect population density and storage time on grain damage and weight loss in maize due to the maize weevil Sitophilus zeamais and the larger grain borer Prostephanus truncatus. Afr. J. Agric Res. 6(10): 2249-2254.
Torres JB, Savedra JLD, Zanuncio JC, \& Waquil JM. 1996. Resistance of sorghum to Sitophilus oryzae (L) and its association with varietal parameters. Int. J. Pest Manag. 42(4): 277-280.

Yasin M. 2009. Accessibility Eating of Insects Pest Weevil and Physico-chemical Factors Affecting It. Proceedings of the National Seminar Cerealia. Pp. 400-409. Maros, July 29, 2009. (in Bahasa Indonesia).

Wulandari S, Oemry S, \& Pangestiningsih Y. 2014. The effect of grain texture on some commodities on the number of pod cultures Sitophilus oryzae L. (Coleoptera: Curculionidae) in the laboratory. Online J. Agroecotech. 2(3): 1189-1195. (in Bahasa Indonesia). 